\title{
PENILAIAN STATUS TROFIK EKOSISTEM TERUMBU KARANG DAN LAMUN DIPERAIRAN SELAT LEMBEH DENGAN APLIKASI INDEKS TRIX \\ (TROPHIC LEVELASESSMENT OF COASTAL AND SEAGRASS ECOSYSTEM IN LEMBEH STRAIT \\ WATERS USING TRIX INDICES APLICATION)
}

\author{
Iis Triyuliantia,*, Eghbert Elvan Ampou ${ }^{a}$, Nuryani Widagtia ${ }^{a}$ I Gede Adi Swastana ${ }^{a}$

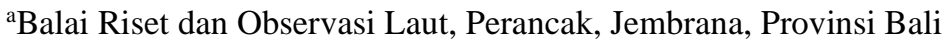 \\ *Koresponden penulis : iisyulianti19@gmail.com
}

\begin{abstract}
Abstrak
Dalam pengelolaan sumber daya perairan dibutuhkan informasi dasar terkait status trofik untuk memberikan gambaran terkait pengkayaan nutrien yang menyebabkan peningkatan kesuburan perairan. Penilaian status trofik berguna untuk menggambarkan tingkat kesuburan suatu perairan. Tingkat kesuburan perairan terukur dari unsur hara dan tingkat kecerahan serta aktivitas biologi lainnya yang terjadi di suatu badan air. Aplikasi indeks TRIX dapat digunakan untuk pemantauan kualitas lingkungan dan telah diaplikasikan untuk penilaian status trofik di lingkungan perairan pesisir. Penilaian status trofik dengan aplikasi indeks TRIX menggunakan kombinasi linear log dari 4 variabel yaitu Klorofil-a, Konsentrasi Oksigen Terlarut (DO), Total Nitrogen (Nitrat, Nitrit dan Amonia) dan Total Fosfat. Hasil penghitungan dengan formula untuk aplikasi indeks TRIX di perairan selat Lembeh diperoleh nilai indeks TRIX keseluruhan stasiun pengamatan adalah 2. Nilai indeks TRIX yang diperoleh menunjukkan bahwa lokasi studi memiliki kategori status trofik yang rendah atau Low Trophic Level. Low Trophic Level menunjukkan nilai indeks TRIX lebih rendah dari 4 yang umumnya berasosiasi atau mencirikan perairan pesisir.
\end{abstract}

Kata kunci: Status Trofik, indeks TRIX, Selat Lembeh, Nutrien, Oksigen Terlarut

\begin{abstract}
Basic information of tropic status or tropic level is needed in terms of aquatic management resources for giving us the description of water enrichment by nutrients that cause the increasing of water productivity. The assessment of tropic status is used for describing waters eutrophication level. The waters eutrophication level is measured from nutrient and the level of transparency waters includes biological activities in those water columns. TRIX index application used for environmental quality monitoring and it has been applied for assessing tropic status in coastal waters. The assessment of tropic status uses a linear logarithmic combination of 4 variables were Chlorophyll-a, concentration of dissolved oxygen, Total Nitrogen (Nitrate, Nitrite, Ammonia) and Phosphate. The result of trophic status assessment in marine coastal of Lembeh strait waters was obtained an index TRIX value for all stations respectively is 2 . Those TRIX index values showed that the level status trophic index in our study location is in Low Tropic Level. Low Tropic Level indicating values lower than 4 TRIX units are associated with scarcely productive coastal waters.
\end{abstract}

Keywords: Trophic Status, TRIX index, Lembeh Strait, Nutrient, Dissolved Oxygen

\section{PENDAHULUAN}

Selat Lembeh merupakan perairan yang memisahkan daratan utama (main land) pulau Sulawesi dengan pulau Lembeh yang terletak di provinsi Sulawesi Utara. Badan perairan ini menyimpan potensi sumber daya ekosistem pesisir dengan keindahan bawah laut serta keanekaragaman biota lautnya. Karakteristik pesisir Selat Lembeh yang membedakannya dengan ekosistem pesisir lainnya masih banyak belum teridentifikasi.

Ekosistem pesisir merupakan wilayah yang unik serta memiliki karakteristik khasdengan keberadaan topografi dan hidrografi lokalnya [1,2] (berupa wilayah yang berbatasan langsung dengan daratan utama (main land) mengakibatkan kawasan ini memiliki area yang produktif serta area yang 
rentan terhadapgangguan serta masukan dari daratan (pengaruh antropogenik) $[3,4]$.

Keberadaan area produktif pada ekosistem pesisir mengakibatkan wilayah ini memiliki peranan secara ekologis dan ekonomis yang tinggi, salah satunya sebagai pengendali ekosistem yang berpengaruh terhadap kondisi sosial dan ekonomi masyarakat di sekitar pantai [2,5]. Diperlukan upaya monitoring dan observasi kawasan pesisir untuk menyediakan data dan informasi terbaru atau terkini agar dapat digunakan sebagai dasar saintifik bagi pengelolaan serta pemanfaatan lokasi tersebut.

Kegiatan pengelolaan dan pemanfaatan ekosistem pesisir membutuhkan gambaran atau deskripsi terkait kondisi kawasan. Salah satu kondisi ekosistem pesisir yang dapat terlihat dan terukur secara ekologi adalah status trofiknya. Status trofik merupakan gambaran atau deskripsi kondisi perairan terutama tingkat kesuburannya yang dapatterlihat dan terukur dari unsur hara (nutrien) dan tingkat kecerahan serta aktivitas biologi lainnya yang terjadi di suatu badan air [6]. Istilah "trofik" umumnya digunakan untuk memberikan gambaran terkait proses feeding, nourishement, potential production dan food web [7].

Status trofik suatu badan perairan dapat terklasifikasi menjadi empat tingkatan status yaitu oligotrofik, mesotrofik, eutrofik dan hipertrofik [8]. Metode penentuan status trofik tersebut berdasarkan kondisi atau kandungan nutrien di suatu badan perairan. Kandungan nutrien mempengaruhi proses biogeokimia di ekosistem perairan laut $[4,9]$.

Aplikasi indeks trofik dapat digunakan untuk kepentingan monitoring dan evaluasi kondisi lingkungan pesisir terutma untuk menunjukkan tingkat kesuburan perairan (nourishment and potential production). Indeks TRIX telah sesuai diaplikasikan untuk lingkungan atau kawasan pesisir seperti yang telah direkomendasikan oleh [10] serta [7]. Selanjutnya ditambahkan $[10,11]$ bahwa penilaian terbaik untuk menentukan status trofik pada perairan pesisir (coastal zone) yakni menggunakan Indeks TRIX.
Indeks TRIX adalah kombinasi linear logaritma dari 4 variabel atau parameter yaitu klorofil-a, persen absolute dari saturasi oksigen (a\%DO), Total Nitrogen (TN) dan Total Fosfat (TF) [10]. Karakteristik lain bahwa indeks TRIX dapat digunakan untuk membandingkan perbedaan spasial dan temporal status trofik pada suatu kawasan. Parameter terukur untuk penentuan indeks TRIX pada penelitian ini meliputi : TN, TP, \% DO, dan klorofil-a.

Analisis klorofil-a dan nutrien di perairan Selat Lembehmenjadi penting untuk dikaji disebabkan lokasi penelitian ini menjadi area perairan yang berbatasan langsung dengan daratan utama yaitu Pulau Lembeh dan Pulau Sulawesi sehingga di duga menerima beban masukan nutrien dari daratan. Kandungan nutrien dalam badan perairan memiliki korelasi terhadap kehidupan biota perairan baik secara langsung maupun tidak langsung terutama terhadap kandungan klorofil-a fitoplankton sebagai indikator tingkat kesuburan perairan.

Masukan nutrien dari daratan utama di duga menjadi salah satu penyebab terjadinya penyuburan atau kondisi perairan dengan status eutrofikasi (status trofik). Informasi mengenai tingkat kesuburan (status trofik) di perairan dapat membantu dalam pengelolaan kualitas perairan yang berkelanjutan. Oleh karena itu, perlu dilakukan penelitian mengenai kandungan klorofil-a, parameter kualitas air serta hubungannya dengan tingkat kesuburan perairan.

Penelitian ini bertujuan untuk memberikan informasi terkait status trofik perairan sekitar ekosistem terumbu karang dan lamun yang berada dalam wilayah atau zona pesisir perairan Selat Lembeh.

\section{METODE}

Penelitian ini dilakukan di perairan sekitar ekosistem terumbu karang dan lamun perairan Selat Lembeh pada Juli 2019. Stasiun penelitian (spasial) terlihat di Gambar 1. Yang ditentukan secara purposive sampling atau untuk merepresentasikan perbedaan spasial karakteristik ekologis lokasi studi (Tabel.1). 


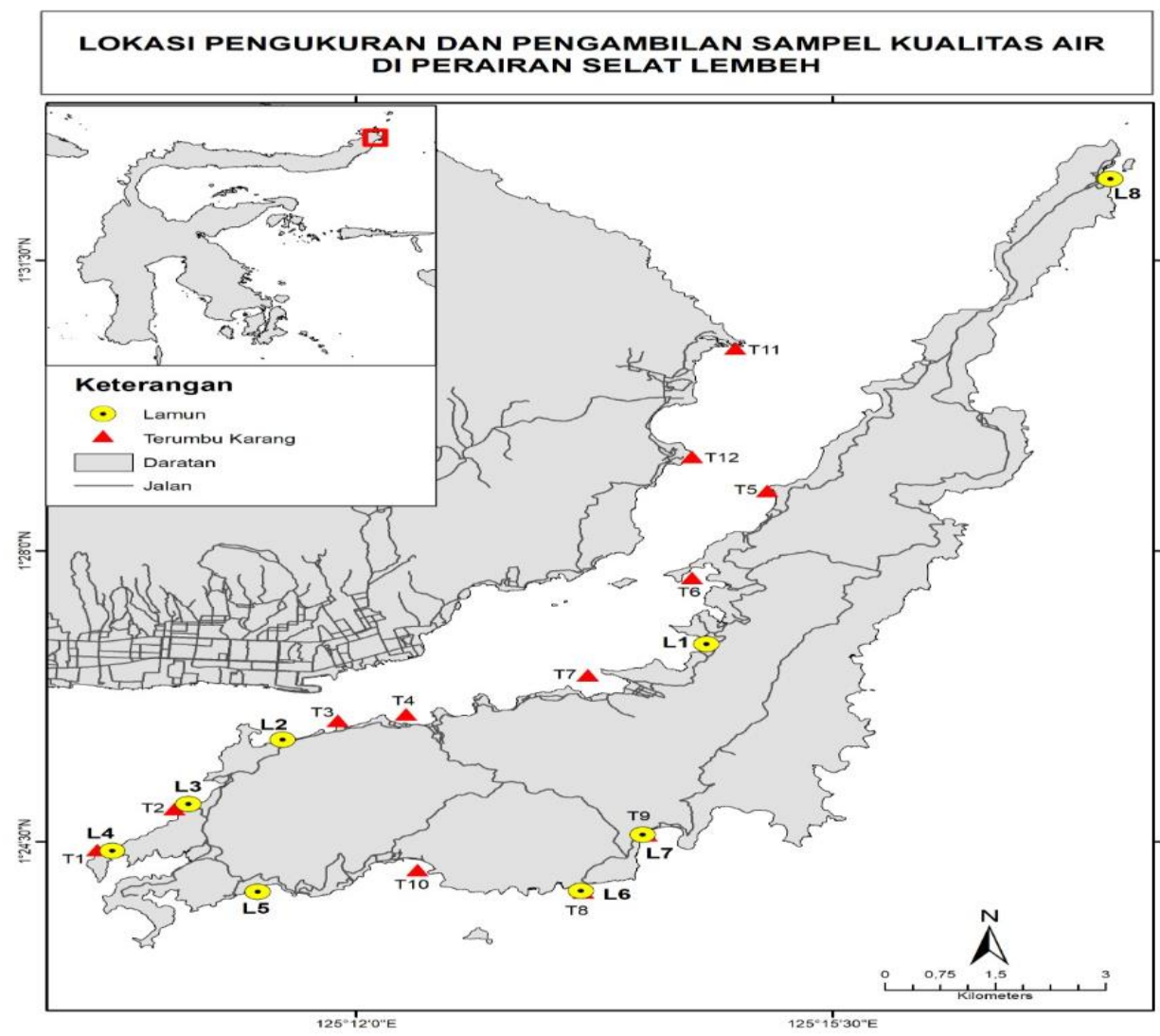

Gambar 1. Titik stasiunpengambilan parameter kualitas air (x) ekosistem terumbu karang dan (o) ekositem lamun

Tabel 1. Keberadaan/KarakteristikTitik Pengambilan Sampel Air

\begin{tabular}{|c|c|c|c|c|}
\hline $\mathrm{T}$ & Sta. & Lokasi/Keberadaan & BUJUR & LINTANG \\
\hline \multirow{6}{*}{$\begin{array}{l}\mathrm{E} \\
\mathrm{R} \\
\mathrm{U} \\
\mathrm{M} \\
\mathrm{B} \\
\mathrm{U}\end{array}$} & $\mathrm{T} 1$ & Kelurahan Paudean, Lodge Dive Resort & E 12510'06.7" & $\mathrm{N} \mathrm{01}{ }^{\circ} 24 ' 23.8^{\prime \prime}$ \\
\hline & $\mathrm{T} 2$ & Kelurahan Paudean2 & E $125^{\circ} 10^{\prime} 40.0^{\prime \prime}$ & 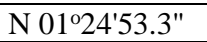 \\
\hline & T3 & Batu Lubang, Tugu Trikora & E $125^{\circ} 11^{\prime} 51.6^{\prime \prime}$ & $\mathrm{N} \mathrm{01}{ }^{\circ} 25^{\prime} 57.2^{\prime \prime}$ \\
\hline & $\mathrm{T} 4$ & Papusungan & E $125^{\circ} 12^{\prime} 22.2^{\prime \prime}$ & $\mathrm{N} \mathrm{01}{ }^{\circ} 26^{\prime} 01.9^{\prime \prime}$ \\
\hline & T5 & Tanjung Kubur, Karekok & E $125^{\circ} 15^{\prime} 01.2^{\prime \prime}$ & 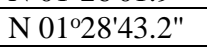 \\
\hline & T6 & Pintu Kota Kecil, Bariri & E $125^{\circ} 14^{\prime} 28.2^{\prime \prime}$ & N 01'27'40.3" \\
\hline \multirow{6}{*}{$\begin{array}{l}\mathrm{K} \\
\mathrm{A} \\
\mathrm{R} \\
\mathrm{A} \\
\mathrm{N} \\
\mathrm{G}\end{array}$} & $\mathrm{T} 7$ & Mawali & E $125^{\circ} 13^{\prime} 42.3^{\prime \prime}$ & N 01²6'30.1" \\
\hline & $\mathrm{T} 8$ & Pancuran 1 & E $125^{\circ} 13^{\prime} 40.4^{\prime \prime}$ & N 012'ㄱ.1" \\
\hline & T9 & Pancuran 2 & E $125^{\circ} 14^{\prime} 08.5^{\prime \prime}$ & N 01'24'34.6" \\
\hline & $\mathrm{T} 10$ & Dorbolang & E $125^{\circ} 12^{\prime} 27.4^{\prime \prime}$ & N 01'24'09.2" \\
\hline & T11 & Batu Angus & E $125^{\circ} 14^{\prime} 46.8^{\prime \prime}$ & N 01³0'26.1" \\
\hline & T12 & Nudi Wall & E $125^{\circ} 14^{\prime} 27.8^{\prime \prime}$ & N 0129'7.76" \\
\hline \multirow{8}{*}{$\begin{array}{l}\mathrm{L} \\
\mathrm{A} \\
\mathrm{M} \\
\mathrm{U} \\
\mathrm{N}\end{array}$} & L1 & Papusungan & E $125^{0} 14^{\prime} 34.2^{\prime \prime}$ & N 01026'54" \\
\hline & $\mathrm{L} 2$ & Batu Lubang & E $125^{0} 11^{\prime} 25.4^{\prime \prime}$ & N 01025'43" \\
\hline & L3 & Paudean & E $125^{\circ} 10^{\prime} 49^{\prime \prime}$ & $\mathrm{N} 01^{0} 25^{\prime} 0.1^{\prime \prime}$ \\
\hline & L4 & Lembeh Lodge/Resort & E $125^{0} 10^{\prime} 13^{\prime \prime}$ & N 01024'24" \\
\hline & L5 & Pasir Panjang & E $125^{0} 11^{\prime} 05^{\prime \prime}$ & N 010 $23^{\prime} 46^{\prime \prime}$ \\
\hline & L6 & Limangu (Pancuran) & E $125^{0} 13^{\prime} 41^{\prime \prime}$ & N 01 $233^{\prime} 53^{\prime \prime}$ \\
\hline & L7 & Pantai Pancuran & E $125^{0} 14^{\prime} 06^{\prime \prime}$ & $\mathrm{N} \mathrm{01} 1^{0} 24^{\prime} 31^{\prime \prime}$ \\
\hline & L8 & Lirang & E $125^{0} 17^{\prime} 34^{\prime \prime}$ & $\mathrm{N} \mathrm{01032'29"}$ \\
\hline
\end{tabular}

Stasiun T8, T9, T10, L5, L6, L7, dan L8

(Gambar 1) yang berada di daerah Pancuran, 
Dorborang, pasir Panjang dan Lirang (Tabel 1) merupakan stasiun yang mempresentasikan lokasi studi yang berbatasan langsung dengan laut Maluku, stasiun lainnya adalah lokasi studi yang berbatasan langsung dengan perairan Selat Lembeh. Pemilihan lokasi studi digunakan sebagai pendekatan spasial untuk mempresentasikan karakteristik perairan Selat Lembeh.

Metode yang banyak digunakan pada dekade terakhir ini untuk penilaian tingkat kesuburan perairan (eutrofikasi) pada badan perairan laut adalah aplikasi indeks TRIX [12]. Aplikasi ini juga dapat diwujudkan dari studi status trofik perairan pesisir melalui pengukuran parameter fisika - kimia perairannya [7].

Indeks TRIX didefinisikan sebagai kombinasi linear logaritma nilai 4 parameter yang berkaitan dengan eutrofikasi yaitu klorofil-a, mineral nitrogen (Jumlah konsentrasi Nitrat, Nitrit, Amonia dalam mg/L) serta total fosfor dan persen deviasi oksigen saturasi [10,12]. Indeks ini meliputi empat paramater yang saling mempengaruhi atau memiliki hubungan sebab akibat dalam proses kesuburan perairan (eutrofikasi).

Status trofik perairan pada penelitian ini ditentukan menggunakan indeks TRIX [10] yang telah di modifikasi pada nilai kriteria konsentrasi nutrien sebagai penentu status trofik yaitu Total Nitrogen (TN). Penentuan status trofik dengan menggunakan kriteria $\mathrm{TN}$ dan Total Fosfat (TP) sebagai penentu status trofik dilakukan oleh [12] dan [13] perhitungan indeks TRIX meliputi: TN, TP, \% DO, dan klorofil-a dengan rumus perhitungannya adalah sebagai berikut:
TRIX $=\frac{(\log 10[C h A+a D \% O+T N+T P]+k)}{m}$

dimana ChA adalah konsentrasi klorofil$\mathrm{a}(\mathrm{mg} / \mathrm{L}), \mathrm{aD} \% \mathrm{O}$ adalah konsentrasi oksigen sebagai persentase absolute deviasi dari saturasi oksigen (100\%), TN adalah Total Nitrogen terdiri dari jumlah nitrat, nitrit dan ammonia (mg/L) dan TP adalah Total Fosfor $(\mathrm{mg} / \mathrm{L})$. Nilai koefisien $\mathrm{k}$ dan $\mathrm{m}$ adalah 1.5 dan 1.2 .

Nilai indeks TRIX memiliki skala 0 - 10 yang dapat dikategorikan dalam 4 klas kategori atau 4 tingkatan (Tabel 2.). Semakin tinggi nilai indeks TRIX (maksimum 10) menunjukkan semakin tinggi tingkat eutrofikasi perairannya (kesuburan perairan tinggi). Kategori tingkat kesuburan yang diperlihatkan dari nilai indeks TRIX mengacu pada [7], dengan kisaran penilaian kategori pada Tabel 2. Kondisi eutrofikasi akan menjadi trigger untuk terjadinya kondisi anoxia [10].

Parameter terukur untuk perhitungan indeks TRIX yaitu TN, TP, \% DO, dan klorofil-a dapat digunakan sebagai parameter indikator tingkat kesuburan perairan [7]. Total Nitrogen (TN) merupakan gambaran konsentrasi Nitrogen anorganik dalam badan perairan laut yang diperoleh dari penjumlahan konsentrasi Nitrat $\left(\mathrm{NO}_{3}\right)$, Nitrit $\left(\mathrm{NO}_{2}\right)$, dan Ammonium $\left(\mathrm{NH}_{4}\right)$, sedangkan bentuk atau jenis Nitrogen lainnya yaitu Nitrous oksida $\left(\mathrm{N}_{2} \mathrm{O}\right)$, Nitrogen dimolekular $\left(\mathrm{N}_{2}\right.$ terlarut), bahan organik mati (partikulat), ion Amonium $\left(\mathrm{NH}_{4}\right)$, Amina Organik $\left(\mathrm{RNH}_{2}\right)$, bahan organik mati (terlarut), biomass hewan, biomassa tumbuhan [15] tidak diukur pada penelitian ini.

Tabel 2. Trofik Kategori berdasarkan Nilai Indeks TRIX menurut [7, 12]

\begin{tabular}{ccl}
\hline Nilai Indeks TRIX & Trofik Kategori & \multicolumn{1}{c}{ Keterangan } \\
\hline$\leq 4$ & Low Trophic Level & Perairan pesisir yang hampir produktif \\
$4-5$ & Middle Trophic Level & Perairan pesisir yang produktif \\
$5-6$ & High Trophic Level & \\
$6-10$ & Very High Trophic & Perairan pesisir yang sangat produktif, hingga \\
& Level & kadang ditemukan kondisi Anoxia \\
\hline
\end{tabular}

Analisa kelarutan oksigen (Dissolved Oxygen) menggunakan metoda Titrimetri [16], sedangkan untuk pengukuran konsentrasi nutrient yang terdiri dari Total Nitrogen (TN) dan Total Fosfat (TP) mengikuti metoda
Spektrofotometri dan konsentrasi klorofil-a menggunakan metode sesuai dengan standar [13]. 


\section{HASIL DAN PEMBAHASAN}

\section{Parameter terukur perhitungan indeks TRIX}

Status trofik perairan ekosistem terumbu karang dan lamun dalam penelitian ini ditentukan secara kuantitatif dengan aplikasi indeks TRIX. Sebaran spasial hasil pengukuran parameter untuk mengaplikasikan indeks TRIX (TN, TP, \% DO, dan klorofil-a) pada lokasi ekosistem terumbu karang terlihat pada Gambar 2. Data hasil pengukuran parameter kualitas perairan yang terdiri dari 4 parameter yaitu TN, TP, \% DO dan klorofil-a memberikan gambaran karakteristik kondisi permukaan perairan, karena pengukuran in situ dan pengambilan air sampel hanya dilakukan di permukaan perairan (kedalaman $0-5$ meter).

Hasil pengukuran konsentrasi nitrogen dalam bentuk Nitrat $\left(\mathrm{NO}_{3}\right)$, Nitrit $\left(\mathrm{NO}_{2}\right)$ dan Ammonia $\left(\mathrm{NH}_{4}\right)$. Konsentrasi ketiga jenis mineral nitrogen tersebut sebagai nilai $\mathrm{TN}$. Hasil pengukuran konsentrasi nutrien di Juni 2019 pada penelitian ini menunjukkan nilai TN perairan ekosistem terumbu karang berkisar antara $0.0159-0.0280 \mathrm{mg} / \mathrm{L}$ dan $0.015-0.034$ $\mathrm{mg} / \mathrm{L}$ untuk perairan ekosistem Lamun (Gambar 2.) sedangkan nilai reratanya adalah $0,02 \pm 0,002 \mathrm{mg} / \mathrm{L}$ dan $0,022 \pm 0,005 \mathrm{mg} / \mathrm{L}$.
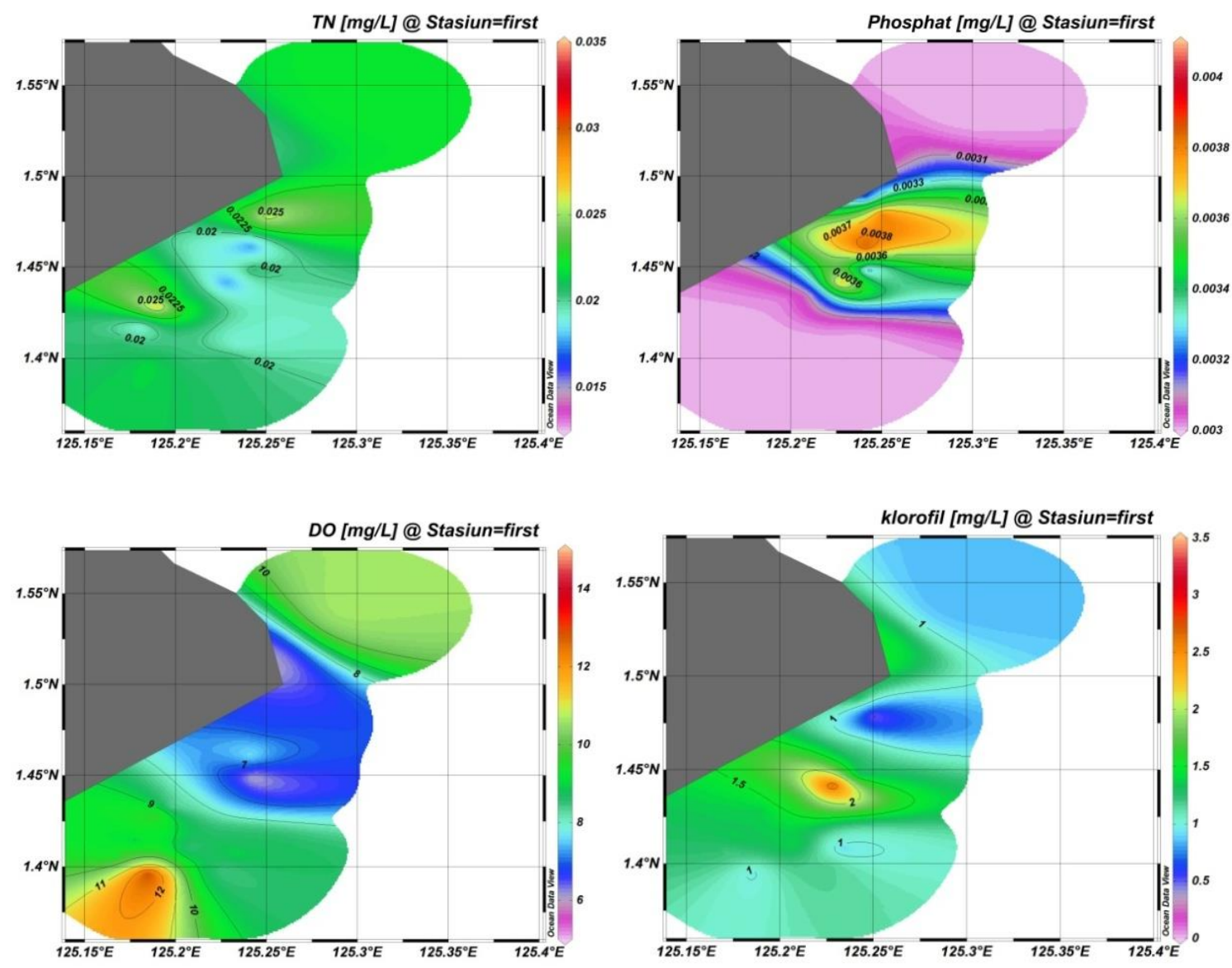

Gambar 2. Sebaran Spasial Konsentrasi TN, TP, DO dan klorofil-a perairan Selat Lembeh

Konsentrasi nitrogen terlarut anorganik dalam bentuk Nitrat $\left(\mathrm{NO}_{3}\right)$ terukur pada penelitian ini berada dibawah kisaran konsentrasi nitrat yang optimum untuk pertumbuhan fitoplankton yaitu $0,9-3,5 \mathrm{mg} / \mathrm{L}$ $\mathrm{mg} / \mathrm{L}$ [17]. Konsentrasi Nitrat perairan yang diperoleh dari pengukuran sampel air dalam penelitian ini berkisar antara $0-1 \mathrm{mg} / \mathrm{L}$ mengindikasikan perairan oligotrofik [18].

Nilai rerata parameter terukur untuk perhitungan indeks TRIX terlihat pada Tabel 2. Perairan ekosistem terumbu karang 
teridentifikasi memiliki nilai rerata suhu permukaan $27,54 \pm 0,8{ }^{\circ} \mathrm{C}$ sedangkan nilai rerata $29,10 \pm 1,05{ }^{\circ} \mathrm{C}$ terukur di perairan ekosistem lamun. Nilai rerata suhu perairan ekosistem lamun ditemukan lebih tinggi dibanding ekosistem terumbu karang. Sebaran nilai suhu terukur pada ekosistem terumbu karang adalah berkisar antara $27,00-29,96{ }^{\circ} \mathrm{C}$ dan $27,56-30,80{ }^{\circ} \mathrm{C}$ (Tabel 2.).

Suhu permukaan perairan di wilayah perairan ekosistem lamun lebih tinggi dibanding perairan ekosistem terumbu karang diduga karena pengaruh tingkat evaporasi yang lebih tinggi di perairan ekosistem lamun. Suhu permukaan perairan tropis dipengaruhi oleh laju evaporasi dan densitas perairan [20]. Dangkalnya kondisi perairan ekosistem lamun saat pengukuran diduga juga mempengaruhi diperolehnya suhu yang lebih tinggi dibanding perairan terumbu karang.

Suhu perairan yang terukur pada lokasi ekosistem lamun masih berada pada kisaran suhu optimum bagi pertumbuhan lamun di daerah tropis dan subtropis yaitu $23-32{ }^{\circ} \mathrm{C}$ [20]. Suhu perairan merupakan salah satu faktor pembatas bagi kehidupan organisme aquatik dan khususnya terumbu karang. Hasil pengukuran suhu di perairan sekitar ekosistem terumbu karang Selat Lembeh diperoleh nilai kisaran suhu $27,00-29,96{ }^{\circ} \mathrm{C}$, menurut [21] kisaran suhu tersebut masih berada kisaran suhu yang optimum bagi pertumbuhan hewan karang kecuali lokasi stasiun T9. Suhu terukur pada stasiun T9 yang berada di daerah pancuran 2 (Gambar 1. dan Tabel 1.) adalah $29,96{ }^{\circ} \mathrm{C}$ dimana menurut [21] suhu tersebut lebih dari $29{ }^{\circ} \mathrm{C}$ dapat mematikan hewan. Rerata suhu permukaan laut bulanan di perairan Indonesia berkisar antara $26-31{ }^{\circ} \mathrm{C}$ [22], hal ini menunjukkan suhu permukaan lokasi studi saat pengukuran masih berada pada kisaran suhu permukaan khas perairan Indonesia.

Hasil pengukuran salinitas permukaan perairan pada lokasi penelitian di sekitar ekosistem lamun memiliki nilai rerata 30,94 \pm 1,24 psu, sedangkan nilai rerata salinitas di perairan sekitar terumbu karang adalah 32,01 \pm 1,70 psu. Kondisi salinitas terukur pada lokasi penelitian di dua lokasi ekosistem khas perairan pesisir (terumbu karang dan lamun) menunjukkan nilai yang berkebalikan (inreverse) dengan suhu. Hasil pengukuran salinitas perairan menunjukkan bahwa lokasi perairan ekosistem terumbu karang dan lamun masih berada pada kisaran nilai salinitas khas permukaan perairan terumbu karang dan lamun di daerah tropis [23] seperti terlihat pada Tabel 3.

Tabel 3. Sebaran Nilai Rerata dan Standar Deviasi (SD) Parameter Terukur

\begin{tabular}{lclcc}
\multicolumn{1}{c}{ Parameter } & Satuan & Nilai Rerata \pm SD & Nilai Maks. & Nilai Min. \\
\hline Ekosistem Terumbu Karang & $(\mathbf{N}=\mathbf{1 2})$ & & & \\
TN & $\mathrm{mg} / \mathrm{L}$ & $0,02 \pm 0,002$ & 0,0159 & 0.0280 \\
Fosfat & $\mathrm{mg} / \mathrm{L}$ & $0,0033 \pm 0,0004$ & 0,015 & 0.034 \\
Klorofil-a & $\mathrm{mg} / \mathrm{L}$ & $1,57 \pm 1,72$ & 0,1 & 1,57 \\
$\%$ DO & $\mathrm{mg} / \mathrm{L}$ & $6,65 \pm 0,05$ & 6,58 & 6,68 \\
Ekosistem Lamun $(\mathbf{N}=\mathbf{8})$ & & & & \\
TN & $\mathrm{mg} / \mathrm{L}$ & $0,022 \pm 0,005$ & 0,004 & 0,003 \\
Fosfat & $\mathrm{mg} / \mathrm{L}$ & $0,003 \pm 0,0$ & 0,003 & 0,003 \\
Klorofil-a & $\mathrm{mg} / \mathrm{L}$ & $0,022 \pm 0,005$ & 0,1 & 1,2 \\
$\%$ DO & $\mathrm{mg} / \mathrm{L}$ & $6,65 \pm 0,11$ & 6,2 & 6,51 \\
\hline
\end{tabular}

Kisaran nilai konsentrasi mineral Fosfat dan klorofil-a yang diperoleh dari hasil pengukuran pada studi pada kedua ekosistem yaitu terumbu karang dan lamun adalah berkisar antara $0,003-0,004 \mathrm{mg} / \mathrm{L}$ dan $0,1-$ $1,57 \mathrm{mg} / \mathrm{L}$. Nilai hasil pengukuran kandungan fosfat dan klorofil-a di wilayah perairan ekosistem terumbu karang dan lamun perairan
Selat Lembeh penelitian ini terlihat lebih rendah untuk kandungan Fosfat perairan yang sama jika dibandingkan dengan hasil pengukuran dilakukan oleh [24].

Hasil pengukuran [24] untuk kandungan fosfat perairan Selat Lembeh diperoleh nilai terukur berkisar antara $0,005-0,011 \mathrm{mg} / \mathrm{L}$ 
dengan nilai rerata adalah $0,008 \pm 0,002 \mathrm{mg} / \mathrm{L}$ seperti terlihat pada Gambar 3.

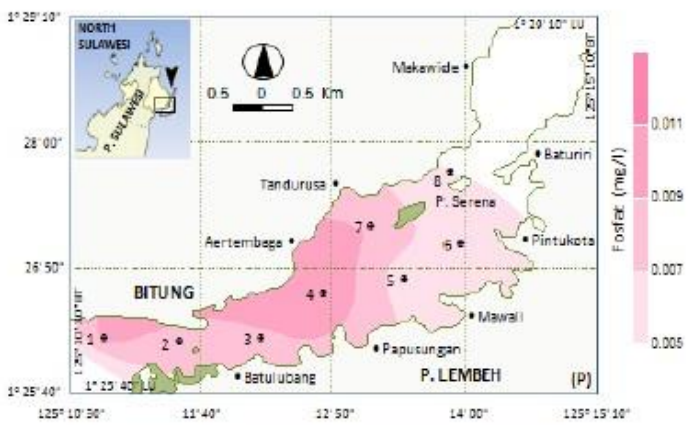

Gambar 3. Sebaran spasial Fosfat permukaan perairan Selat Lembeh terukur di bulan Juli 2013 [26].

Kesamaan hasil terlihat dari sebaran spasial nilai kandungan fosfat terukur pada lokasi yang sama di tahun 2013 dan 2019 (Gambar 2 dan 3) yaitu di stasiun T4 di daerah Papusungan dan Aertembaga. Stasiun dan lokasi tersebut ditemukan konsentrasi tertinggi kandungan Fosfat jika dibandingkan dengan stasiun lainnya.

Parameter nutrien terukur untuk penilaian kesuburan menggunakan indeks aplikasi TRIX adalah Total Nitrogen (TN) dan Fosfat. Konsentrasi TN menggambarkan konsentrasi nitrogen sebagai unsur terbesar udara dapat berdifusi dalam badan perairan melalui proses pengadukan [14], sedangkan kandungan Fosfat perairan memainkan peranan penting dalam proses transformasi energy selama proses fotosintesis oleh fitoplankton [27]. Keduanya (Nitrogen dan Fosfat) merupakan faktor pembatas pertumbuhan bagi fitoplankton. Kadar nitrogen yang berlebihan, dapat memicu gas disease organisme akuatik tingkat tinggi seperti memicu blooming fitoplankton [12].

Konsentrasi oksigen terlarut (DO) terukur pada lokasi studi (Tabel 2 dan Gambar 2) menunjukkan nilai kisaran yang berada diatas ambang baku mutu yaitu $\geq 5 \mathrm{mg} / \mathrm{L}$ [26]. Hasil pengukuran menunjukkan kondisi lingkungan perairan Selat Lembeh masih mendukung untuk kehidupan biota laut. Kondisi yang sama juga terlihat dari hasil pengukuran klorofil-a (Tabel 2 dan Gambar 2) juga masih berada pada kisaran baku mutu untuk biota laut [26] dan berada pada kisaran nilai klorofil-a terukur di permukaan perairan yang masih dapat mendukung untuk perikanan $[27,28]$

Konsentrasi oksigen yang digunakan dalam perhitungan indeks aplikasi TRIX merupakan prosentase kadar saturasi oksigen terlarut (\% DO). Persentase ini merupakan gambaran oksigen di perairan berdasarkan perhitungan hubungan kadar oksigen terlarut in-situ dan oksigen teroritis pada tekanan 760 mmHg [29]. [12] menjelaskan bahwa kadar saturasi oksigen adalah persentase $(\%)$ kadar oksigen terlarut (DO) dibandingkan dengan oksigen teoritis pada suhu atau suhu tertentu. Parameter klorofil-a fitoplankton, digunakan sebagai indikator besaran organisme fotosintetik perairan. Deviasi kadar saturasi oksigen (\% DO) dan kadar klorofil-a dalam indeks TRIX menggambarkan produktivitas perairan ekosistem terumbu karang dan lamun di Selat Lembeh

\section{Penilaian Trofik Status dengan Aplikasi Indeks TRIX}

Hasil pengukuran parameter untuk penilaian tropik status dengan aplikasi indeks TRIX diperoleh sebaran nilai seperti terlihat pada Gambar 4. Penentuan kategori trofik status perairan berdasarkan [12] menunjukkan ke-4 (empat) parameter terukur menempatkan trofik status perairan ekosistem terumbu karang dan lamun Selat Lembeh berada pada tingkat atau kategori yang rendah (Low Trophic Level). 

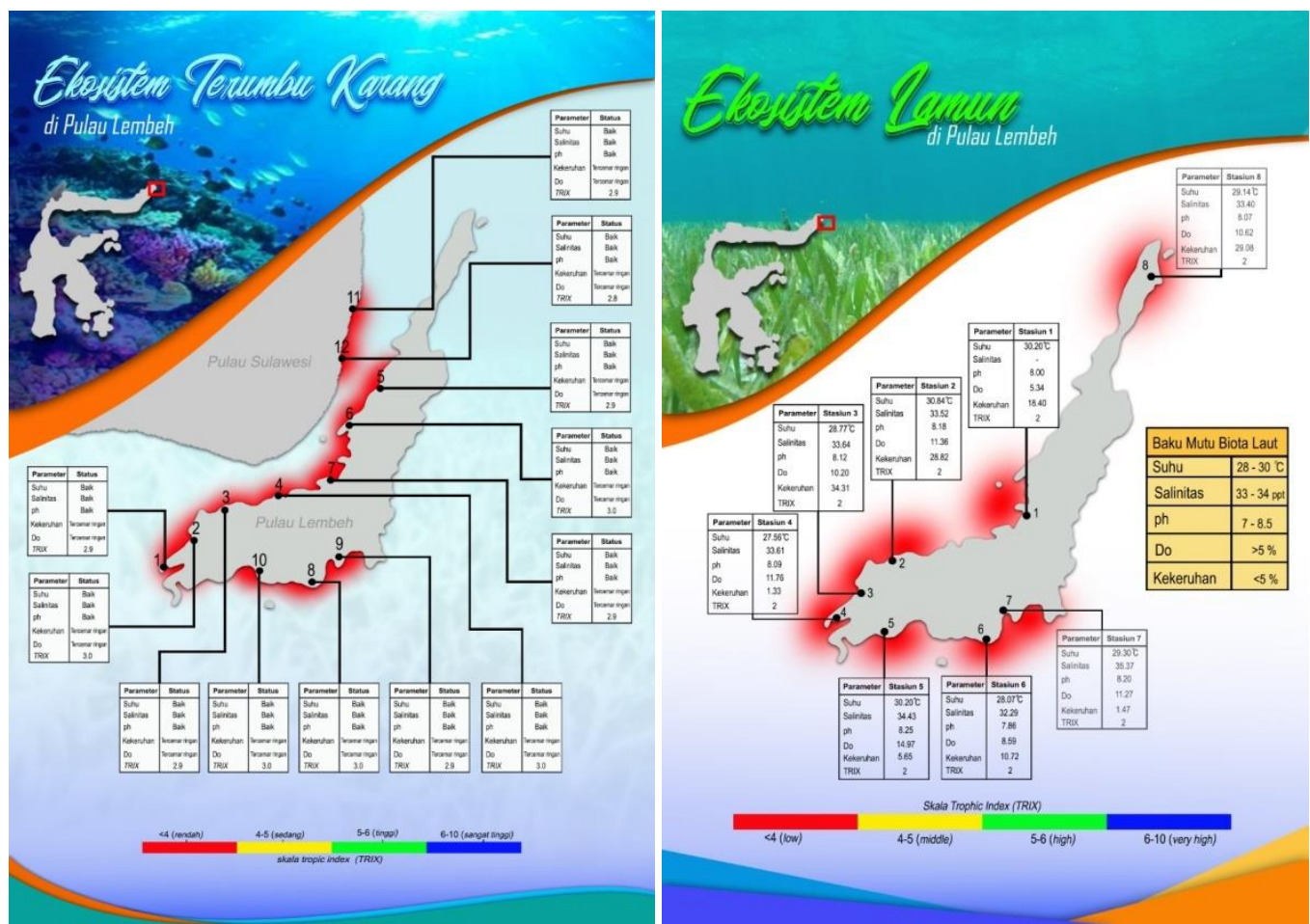

Gambar 4. Sebaran Spasial Nilai Status Trofik dengan Aplikasi Indeks TRIX

Status trofik yang dihitung dan dinilai dari empat parameter kualitas air yaitu TN, TP, \% DO, dan klorofil-a diperoleh nilai indeks sebesar 2 untuk seluruh stasiun menunjukkan kondisi perairan berada pada status oligotrofik atau miskin zat hara [6,12]. Nilai indeks TRIX ini sekaligus menunjukkan bahwa perairan di sekitar terumbu karang dan lamun sebagai ekosistem khas pesisir daerah tropis sebagaimana yang diungkapkan oleh [30].

Kondisi miskin hara terlihat dari nilai konsentrasi TN dan Fosfat (Tabel 2 dan gambar 2) masuk dalam kategori rendah diduga sebagai akibat tingkat pemanfaatan yang tinggi oleh organisme yang berasosiasi dalam kawasan perairan Selat Lembeh. Ekosistem terumbu karang dan lamun merupakan dua ekosistem yang berbatasan langsung dengan daratan utama sehingga sangat memungkinkan adanya masukan nutrien dari daratan (antropogenik) [3,4,30]. Aliran nutrien dari darat (antropogenik) masuk ke perairan laut dapat meningkatkan atau menjadi sumber nutrien dari luar (external source) ke badan perairan [3,4].

Sumber nutrien (TN dan Fosfat) badan perairan umumnya selain dari lingkungan luar (external source) juga bersumber dari internal yaitu proses metabolisme organisme perairan dan dekomposisi bahan-bahan organik oleh bakteri $[3,4,30]$. Kedua jenis bahan mineral tersebut merupakan faktor pembatas pertumbuhan biota laut [24] dengan perbandingan Redfield Ratio di ekosistem perairan adalah $6: 1[3,4]$.

Status trofik perairan ekosistem terumbu karang dan lamun Selat Lembeh terhitung dengan aplikasi indeks TRIX termasuk dalam tingkat Low Level Trophic atau dikenal dengan istilah oligotrofik. Status oligotrofik perairan pesisir Selat lembeh ini menurut [30] umumnya berasosiasi atau mencirikan perairan pesisir.

\section{KESIMPULAN}

Perairan ekosistem terumbu karang dan lamun Selat Lembeh teridentifikasi memiliki konsentrasi mineral nitrogen dalam bentuk Total Nitrogen dan Fosfat yang rendah dan masuk dalam kategori oligotrofik. Konsentrasi klorofil-a dan oksigen terlarut menunjukkan produktivitas perairan ekosistem terumbu karang dan lamun di Selat Lembeh masih mendukung kehidupan biota. Status trofik dari hasil perhitungan dengan aplikasi indeks TRIX 
menunjukkan perairan berada dalam kategori Low Trophic Level.

\section{UCAPAN TERIMA KASIH}

Penulis mengucapkan terima kasih kepada APBN BROL TA 2019 yang telah mendanai penelitian ini dan terimakasih juga untuk para peneliti dan pembantu lapang yang telah memberikan bantuan selama di lokasi penelitian.

\section{DAFTAR PUSTAKA}

[1] Dahuri, Rochimin dkk. 1996. Pengelolaan Sumber Daya Pesisir dan Lautan Secara Terpadu. Jakarta.

[2] Clark, J. R. 1996. Coastal zone management handbook. Lewis Publishers, New York, 694 pp

[3] Dugdale, R.C. and J.J. Goering, "Uptake of New and Regenerated Forms of Nitrogen in Primary Productivity", Limnology and Oceanography, Vol.12, Issue.2, pp. 196 - 206, April 1967

[4] Ryther and Dunstan Ryther, J.H., W. M. Dunstan, K. R. Tenore and J. E. Huguenin, "Controlled Eutrophication: Increasing Food Production from the Sea by Recycling Human Wastes", BioScience, Vol. 22, No. 3, pp. 144-152, Mar. 1972

[5] Barbier, E. B., S.D. Hacker, C. Kennedy, E.W. Koch, A.C. Stier, B.R. Silliman, "The Value of Estuary and Coastal Ecosystems Services", Ecological Monographs, Vol.81, Issue 2, pp. 169193, May 2011

[6] Zulfia, N dan Aisyah, "Status Trofik Perairan Rawa Pening Ditinjau dari Kandungan Unsur Hara (NO3 dan PO4) serta Klorofil-a", Vol 5. No.3, pp.189199, 2013

[7] Pavluk, T. and A. Vaate, "Trophic Index and Efficiency", Reference Module in Earth Systems and Environmental Sciences, Elsevier, 2017

[8] Hakanson, L and A.C. Bryann, "Eutrophication in the Baltic Sea Present Situation, Nutrien Transport Processes, Remedial Strategies", Springer-Verlag Berlin Heidelberg, 261 hlm, 2008
[9] Giovanardi, F. and R.A. Vollenweider, "Trophic conditions of marine coastal waters: experience in applying the Trophic Index TRIX to two areas of the Adriatic and Tyrrhenian seas", $J$. Limnol., 63(2): 199-218, 2004.

[10] Seisdedo, M., A.R Moreira., A.A Comas., and G.Arencibia, "Analysis of Tools For Tropic Status Assesment of Water in Cienfuegos Bay, Cuba",(PANAMJAS) Pan- American Journal of Aquatic Sciences, Vol. 9(2): 103-11, 2014.

[11] Vollenweider, R.A., F. Giovanardi., G. Montanari, and A. Rinaldi, "Characterization of the Trophic Conditions of marine coastal waters with Special Reference to the NW Adriatic Sea: Proposal for a Trophic Scale, Turbidity and Generalized Water Quality Index', Environmetrics, 9(3), pp.329-357, 1998.

[13] Smith, V.H, Tilman GD, and Nekola JC, "Eutrophication: impacts of excess nutrient inputs on freshwater, marine, and terrestrial ecosystems", Environ Pollut, Vol 100, Hal. 179-196,1999.

[14] APHA, "Standard Methods for the Examination of Water and Wastewater", 21st Edition, American Public Health Association/American Water Works Association/Water Environment Federation, Washington DC, 2005.

[15] D. Setiapermana, "Siklus Nitrogen di Laut", Oseana, Volume XXXI, Nomor 2, Hal.19 - 3, 2006.

[16] Strickland, J.D.H. dan T.R. Parsons, "Determination of dissolved oxygen, A practical hand book of sea water analisis", Bulletin 167, Fisheries research boord of Canada, Ottawa, pp. $21-27,1968$

[17] Wardoyo STH, "Water quality management center for environmental resource management studies", Bogor Ipb Press, 1982

[18] Iswanto C, Hutabarat S, Purnomo PW, "Analysis of aquatic fertility based on diversity of Plankton, Nitrates and diversity of Plankton, Nitrates and Phosphates in Jali River and Slope River of Keburuhan Village, Purworejo", Aquares, Vol.4, No.3, Agustus 2015 
[19] Tchernia, P, "Descriptive Regional Oceanography", Pergamon marine series, Vol.3. Laboratoire d'Oceanographic Physique, Museum National d'Histoire, 1980.

[20] Lee, K.S., S.R. Park. and Y.K. Kim, "Effect of irradiance, temperature, and nutrients on growth dynamics of seagrasses: A Review", J. od Experimental marine Biology and Ecology, Vol.350, pp. 144-175, 2007

[21] Molles Jr, C.M., "Ecology Concepts \& Applications", Fourth Edition. University of Mexico, Mexico, 2008

[22] Gaol, L.J., E.R. Arhatin dan M.M. Ling, "Pemetaan Suhu Permukaan Laut dari Satelit di Perairan Indonesia', Seminar Nasional, Penginderaan Jauh, Bogor, hlm 433- 442, 2014.

[23] Nybakken, J.W., "Biologi Laut Suatu Pendekatan Ekologis", Terjemahan M. Ediman, Koesoebiono, D.G Bengen, M. Hutomo, \& S. Sukardjo, Jakarta, PT. Gramedia, 1988

[24] Patty, S.I., "Karakteristik Fosfat, Nitrat dan Oksigen Terlarut di perairan Selat lembeh, Sulawesi Utara", Jurnal Pesisir dan laut Tropis, Vol.2 No.1, 2015

[25] Wetzel, R., "Limnology", 2nd Edition. Philadelphia, Saunders College Publishing, 1983

[26] Keputusan Kementrian Lingkungan Hidup No 51 Tahun 2004, "Baku Mutu Air Laut untuk Biota Laut", Kementrian Negara Bidang Lingkungan Hidup Republik Indonesia, 2004

[27] Triyulianti, I., I. Hermawan, A. Yunanto, N. A. Pradisty., A.C. Raymonza, F. Islamy., N.C.Magdalena, "Profil Vertikal Kandungan Oksigen terlarut dan Floresense in Vivo sebagai Indikator Keberlangsungan Kehidupan di Perairan Laut Maluku dan Laut Sulawesi”, Jurnal Kelautan Nasional, Vol.12, No.2. 2017

[28] Cole G.A., "Text Book of Limnology", Third Edition. Waveland Press Inc. United States of America, 1983

[29] Barbier, E.B., S.D Hacker, C. Kennedy, E.W. Koch, A.C Stier, B. R. Silliman., "The Value of Estuarine and Coastal Ecosystem Services", Ecological Monograph. Vol. 81(2). pp 169-193, 2011

[30] Welsh, D.T., "Review: Nitrogen фxation in seagrass meadows: Regulation, plantbacteria interactions and signiфcance to primary production", Ecol. Lett. 3, pp. $58-71,2000$ 